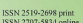

НАУКОВИЙ ВІСНИК

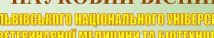

Dimitiog.

cientific messenger of Lviv National University

Weterinary

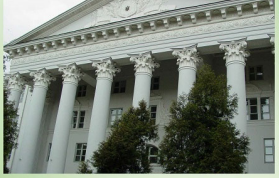

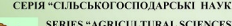

Том 23 № 94

2021
Науковий вісник Яьвівського національного університету ветеринарної медицини та біотехнодогій імені С.3. Гжицького. Серія: Сільськогосподарські науки

\section{Scientific Messenger of Lviv National University of Veterinary Medicine and Biotechnologies. Series: Agricultural sciences}

doi: 10.32718/nvlvet-a9421

https://nvlvet.com.ua/index.php/agriculture

UDC 636.4.082.43

\title{
Level of phenotypic consolidation and correlation analysis of reproductive qualities of sows of different breeding value
}

\author{
V. I. Khalak ${ }^{1}$, B. V. Gutyj ${ }^{2}$, O. M. Bordun ${ }^{3}$, O. I. Stadnytska ${ }^{4}$, S. E. Chernyavsky ${ }^{1}$ \\ ${ }^{1}$ State Institution Institute of Grain Crops of NAAS of Ukraine, Dnipro, Ukraine \\ ${ }^{2}$ Stepan Gzhytskyi National University of Veterinary Medicin and Biotechnologies Lviv, Ukraine \\ ${ }^{3}$ Institute of Agriculture of the North-East of NAAS of Ukraine, v. Sad, Sumy region, Ukraine \\ ${ }^{4}$ Institute of Agriculture of the Carpathian region of NAAS of Ukraine, v. Obroshino, Lviv region, Ukraine
}

\section{Article info}

Received 01.03.2021

Received in revised form 01.04 .2021

Accepted 02.04.2021

State Institution Institute of grain crops of NAAS, V. Vernadsky Str., 14, Dnipro, 49027, Ukraine. Tel.: +38-067-892-44-04 E-mail:v16kh91@gmail.com

Stepan Gzhytskyi National University of Veterinary Medicine and Biotechnologies Lviv, Pekarska Str., 50, Lviv, 79010, Ukraine.

Institute of Agriculture of the North-East of NAAS of Ukraine, Zelena Str., 1, v. Sad, Sumy region, 42343, Ukraine.

Institute of Agriculture of the Carpathian region of the National Academy of Agrarian Sciences of Ukraine Grushevskogo Str. 5, Obroshino, Pustomytovsky District Lviv Region, 81115, Ukraine
Khalak, V. I., Gutyj, B. V., Bordun, O. M., Stadnytska, O. I., \& Chernyavsky, S. E. (2021). Level of phenotypic consolidation and correlation analysis of reproductive qualities of sows of different breeding value. Scientific Messenger of Lviv National University of Veterinary Medicine and Biotechnologies. Series: Agricultural sciences, 23(94), 117-122. doi: 10.32718/nvlvet-a9421

The results of research activities of reproductive qualities of sows of different breeding value are given, the level of their phenotypic consolidation is determined and the correlation analysis is carried out. The study was conducted in agricultural formations of Dnipropetrovsk and Sumy regions (LLC "AF "Renaissance", research farm of the Institute of Agriculture of the Northeast NAAS of Ukraine, LLC "DruzhbaKaznacheyivka"), livestock laboratory of the State Institution Institute of Grain Crops of NAAS of Ukraine and livestock laboratory economy of the North-East of NAAS of Ukraine. The work was performed according to the research program of NAAS of Ukraine № 30 "Innovative technologies of breeding, industrial and organic production of pig products" ("Pig breeding"). The object of the study were sows of large white breed. Indicators of reproductive qualities of animals of the specified production group were investigated taking into account the following quantitative signs: multiplicity, head; milk yield, kg, number of piglets at weaning, head; nest weight at the time of weaning at the age of 28 days, $\mathrm{kg}$, safety, \%. The BLUP index (maternal line) was calculated on the basis of the Main Breeding Center for Pig Breeding (Institute of Pig Breeding and AIP NAAS of Ukraine) according to the general model of a single animal. The index of alignment (homogeneity) of the sow's nest by live weight of piglets at the time of their birth, the index of reproductive qualities of the sow and the coefficients of phenotypic consolidation of the main quantitative traits were calculated according to the methods of V. I. Khalak (2012), M. D. Berezovsky (quoted from A. Vashchenko, 2019) and Yu. P. Polupan (1996, 2005), respectively. Biometric processing of research results was performed according to the methods of G. F. Lakin (1990). It was found that the maximum indicators of fertility, milk yield, number of piglets and nest weight at the time of weaning at the age of 28 days are characterized by sows of group I, in which the index BLUP (maternal line) is 109.78-128.75, the index of reproductive qualities (CPI) - 101.43-161.72 points. The correlation coefficients between the characteristics of reproductive qualities and integrated indicators are reliable and range from $+0.648 \pm 0.0492$ (index BLUP (maternal line) $\times$ milk yield) to $+0.984 \pm 0.0086$ (index of reproductive qualities (IRQ) $\times$ nest weight per weaning time at the age of 28 days). A high level of phenotypic consolidation on the basis of reproductive qualities of sows was found in animals of group II by milk yield $\left(K_{1}=0.561, K_{2}=0.499\right)$ and nest weight at the time of weaning at the age of 28 days $\left(K_{1}=0.521, K_{2}=0.472\right)$, peers of group $I-$ by multiplicity $\left(K_{l}=\right.$ $\left.0.315, K_{2}=0.410\right)$ and the number of piglets at weaning $\left(K_{I}=0.296, K_{2}=0.397\right)$. The calculation of economic efficiency of sows of different breeding value shows that the maximum increase in additional products was obtained from sows of group I, in which the index BLUP (maternal line) is 109.78-128.75, the index of reproductive qualities (IRQ) - 101.43-161, 72 points $-+13.08 \%$, and its value is +332.08 UAH/head. These indicators of evaluation indices are a criterion for selecting high-yielding sows of large white breeds of controlled herds.

Key words: sow, breed, breeding value, reproductive qualities, index, phenotypic consolidation coefficient, variability, correlation. 


\title{
Рівень фенотипної консолідації та кореляційний аналіз ознак відтворювальних якостей свиноматок різної племінної цінності
}

\author{
В. І. Халак ${ }^{1}$, Б. В. Гутий ${ }^{2}$, О. М. Бордун ${ }^{3}$, О. І. Стадницька ${ }^{4}$, С. С. Чернявський ${ }^{1}$ \\ ${ }^{1}$ Державна установа Інститут зернових культур НААН України, м. Дніпро, Україна \\ ${ }^{2}$ Львівський національний університет ветеринарної медицини та біотехнологій імені С. 3. Гжиџького, м. Львів, \\ Україна \\ ${ }^{3}$ Інститут сільського господарства Північного Сходу НААН Украӥни, с. Сад, Сумська область, Україна \\ ${ }^{4}$ Інститут сільського господарства Карпатського регіону НААН Украӥни, с. Оброчине, Львівська область, \\ Україна
}

Наведено результати досліджень відтворювальних якостей свиноматок різної племінної иінності, визначено рівень їх фенотипної консолідації та проведено корелячійний аналіз. Дослідження проведено в агроформуваннях Дніпропетровської та Сумської областей (ТОВ “АФ “Відродження”, дослідне господарство Інституту сільського господарства Північного Сходу НААН Украӥни, СТОВ “Дружба - Казначеївка”), лабораторї тваринництва Державної установи Інститут зернових культур НААН Украӥни та лабораторії тваринництва і кормовиробництва Інституту сільського господарства Північного Сходу НААН України. Робота виконана згідно з програмою наукових досліджень НААН України № 30 "Інноваційні технології племінного, промислового та органічного виробництва продукиії свинарства” (“Свинарство”). Об'єктом дослідження були свиноматки великої білої породи. Показники відтворювальних якостей тварин зазначеної виробничої групи досліджували з урахуванням таких кількісних ознак: багатоплідність, гол; молочність, ке; кількість поросят на час відлучення, гол; маса гнізда на час відлучення у віці 28 діб, кг; збережсеність, \%. Індекс BLUP (материнська лінія) розраховували на базі Головного селекиійного центру зі свинарства (Інститут свинарства і АПВ НААН Украӥни) за загальною моделлю одиничної тварини. Індекс вирівняності (однорідності) гнізда свиноматки за живою масою поросят на час їхнього народження, індекс відтворювальних якостей свиноматки та коефіцієнти фенотипної консолідації основних кількісних ознак розраховували за методиками В. І. Халака (2012), М. Д. Березовського (цит. за П. А. Ващенко, 20I9) та Ю. П. Полупана $(1996,2005)$ відповідно. Біометричну обробку результатів досліджень проводили за методиками Г. Ф. Лакіна (1990). Встановлено, що максимальними показниками багатоплідності, молочності, кількості поросят та маси гнізда на час відлучення у вічі 28 діб характеризуються свиноматки I групи, у яких індекс ВLUР (материнська лінія) дорівнює 109,78-128,75, індекс відтворювальних якостей (IBК) - 101,43-161,72 бала. Коефічієнти корелячії між ознаками відтворювальних якостей та інтегрованими показниками є достовірними і коливаються у межах від +0,648 \pm 0,0492 (індекс BLUP (материнська лінія) $\times$ молочність) до +0,984 \pm 0,0086 (індекс відтворювальних якостей (ІВК) × маса гнізда на час відлучення у віці 28 діб). Високий рівень фенотипної консолідаиії за ознаками відтворювальних якостей свиноматок виявлено у тварин II групи за молочністю (К $=0,561$, $\left.K_{2}=0,499\right)$ та масою гнізда на час відлучення у вічі 28 діб $\left(K_{1}=0,521, K_{2}=0,472\right)$, ровесниць I групи - за багатоплідністю $\left(K_{1}=\right.$ 0,315, $\left.K_{2}=0,410\right)$ та кількістю поросят на час відлучення $\left(K_{1}=0,296, K_{2}=0,397\right)$. Розрахунок економічної ефективності використання свиноматок різної племінної ичінності свідчить, щзо максимальну прибавку додаткової продукиії одержано від свиноматок I групи, у яких індекс BLUP (материнська лінія) дорівнює 109,78-128, 75, індекс відтворювальних якостей (IВК) - 101,43-161,72 бала - +13,08\%, а їі вартість становить +332,08 грн/гол. Зазначені показники очіночних індексів є критерієм відбору висопродуктивних свиноматок великої білої породи підконтрольних стад.

Ключові слова: свиноматка, порода, племінна иінність, відтворювальні якості, індекс, коефіцієнт фенотипної консолідації, мінливість, кореляція.

\section{Вступ}

Оцінка племінної цінності свиней суттєво впливає на успіх в селекційно-племінній роботі, а ії результати дають можливість виключити 3 процесу відтворення тварин, продуктивність яких не відповідає вимогам сучасної економіки. А тому важливим напрямком досліджень є пошук ефективних методів оцінки та відбору високопродуктивних тварин у підконтрольних популяціях, збільшення поголів'я тварин з високим рівнем фенотипної консолідації за основними кількісними ознаками та інтенсивне їх використання (Bazhov \& Komlatskiy, 1989; Berezovs'kyy \& Khat'ko, 2005; Chinarov et al., 2007; Ibánẽz-Escriche et al., 2008; Danshin, 2008; Tserenyuk et al., 2010; Balatsky et al., 2012; Rybalko \& Floka, 2014; Schiavo et al., 2015; Voloshchuk \& Khalak, 2015; Khalak, 2015; Kozyr et al., 2019; Khalak, 2020; Khalak et al., 2020).

Метою роботи було дослідити відтворювальні якості свиноматок різної племінної цінності, визначити рівень їх фенотипної консолідації та провести кореляційний аналіз.

\section{Матеріал і методи досліджень}

Дослідження проведено в агроформуваннях Дніпропетровської та Сумської областей (ТОВ “АФ “Відродження”, дослідне господарство Інституту сільського господарства Північного Сходу НААН України, СТОВ “Дружба - Казначеївка"), лабораторії тваринництва Державної установи Інститут зернових культур НААН України та лабораторії тваринництва i кормовиробництва Інституту сільського господарства Північного Сходу НААН України. Робота виконана згідно 3 програмою наукових досліджень НААН України № 30 “Інноваційні технології племінного, промислового та органічного виробництва продукції свинарства” (“Свинарство”).

Об'єктом дослідження були свиноматки великої білої породи. Показники відтворювальних якостей тварин зазначеної виробничої групи досліджували 3 урахуванням таких кількісних ознак: багатоплідність, гол; молочність, кг; кількість поросят на час відлучення, гол.; маса гнізда на час відлучення у віці 28 діб, кг; збереженість, \%.

Індекс BLUP (материнська лінія) розраховували на 
базі Головного селекційного центру 3 свинарства (Інститут свинарства і АПВ НААН України) за загальною моделлю одиничної тварини.

Комплексну оцінку свиноматок за ознаками відтворювальних якостей проводили за індексом вирівняності (однорідності) гнізда свиноматки за живою масою поросят на час їхнього народження (1) та індексом відтворювальних якостей свиноматки (IBK) (2):

$$
I B \Gamma_{0}=\frac{n}{2,5-\left(\frac{x_{\max }-x_{\min }}{\bar{X}}\right)}
$$

де: $І В \Gamma_{0}$ - індекс вирівняності (однорідності) гнізда свиноматки за живою масою поросят на час їх народження, бала; n - багатоплідність, гол.; 2,5 - максимальний показник живої маси одного поросяти на час народження, кг; $x$ max - жива маса поросяти у гнізді з максимальним показником, кг; $x$ min - жива маса поросяти у гнізді з мінімальним показником, кг; $\bar{X}$ середня жива маса поросяти у гнізді на час народження (великоплідність свиноматок), кг (Khalak, 2012);

$$
I B K=\left(1,1 \times X_{1}\right)+\left(0,3 \times X_{2}\right)+\left(3,3 \times X_{3}\right)+\left(0,67 \times X_{4}\right)(2)
$$

де: $I B K$ - індекс відтворювальних якостей свиноматки, бала; $\mathrm{X}_{1}$ - багатоплідність, гол; $\mathrm{X}_{2}$ - маса поросят у 21-денному віці (молочність), кг; $\mathrm{X}_{3}$ - кількість поросят на час відлучення, гол.; $\mathrm{X}_{4}-$ маса гніда на час відлучення, кг (Sheiko et al., 2008).

Коефіцієнти фенотипної консолідації $(3,4)$ та економічну ефективність результатів досліджень (5) розраховували за формулами:

$$
\begin{aligned}
& K_{1}=1-\frac{\sigma_{2}}{\sigma_{3}} \\
& K_{2}=1-\frac{C v_{2}}{C v_{3}}
\end{aligned}
$$

де: $\sigma_{2}$ i $\mathrm{C}_{\mathrm{v} \text { г }}$ - середньоквадратичне відхилення та коефіцієнт мінливості оцінюваної групи тварин за конкретною ознакою, $\sigma_{3} \mathrm{i}_{\mathrm{v} 3}-$ середньоквадратичне відхилення та коефіцієнт мінливості генеральної сукупності (Полупан, 1996);

$$
E=Ц \times \frac{C \times \Pi}{100} \times \pi \times K
$$

де: Е - вартість додаткової продукції, грн; Ц - закупівельна ціна одиниці продукції відповідно до існуючих цін, які діють в Україні; С - середня продуктивність тварин; П - середня надбавка основної продукції (\%), яка виражена у відсотках на 1 голову при застосуванні нового і поліпшеного селекційного досягнення порівняно з продуктивністю тварин базового використання; Л - постійний коефіцієнт зменшення результату, який пов'язаний з додатковими витратами на прибуткову продукцію $(0,75)$; К - чисельність поголів'я сільськогосподарських тварин нового або поліпшеного селекційного досягнення, голів (Metodika opredeleniya ekonomicheskoy effektivnosti ..., 1983).

Результати досліджень опрацьовано методом варі- аційної статистики за методикою Лакіна Г. Ф. (Lakin, 1990).

\section{Результати та їх обговорення}

Аналіз даних відтворювальних якостей свиноматок з урахуванням їх внутрішньопородної диференціації за індексом BLUP (материнська лінія) свідчить, що різниця між тварин I і II груп за багатоплідністю дорівнює 3,5 гол. ( $\mathrm{td}=10,60, \mathrm{P}<0,001)$, молочністю 17,5 кг $(\mathrm{td}=10,86, \mathrm{P}<0,001)$, кількість поросят на час відлучення $-3,0$ гол. ( $\mathrm{td}=12,00, \mathrm{P}<0,001)$, масою гнізда на час відлучення у віці 28 діб - 18,3 кг (td = $10,57, \mathrm{P}<0,001)$ і індексом відтворювальних якостей (IBK) - 31,07 бала $(\mathrm{td}=11,50, \mathrm{P}<0,001)$ (табл. 1$)$.

За великоплідністю та індексом вирівняності (однорідності) гнізда свиноматки за живою масою поросят на час їхнього народження IBГ 0 різниця між тваринами II та I груп дорівнює 0,08 кг (td $=3,33$, $\mathrm{P}<0,01)$ i 1,72 бала $(\mathrm{td}=10,11, \mathrm{P}<0,001)$.

Результати розрахунку коефіцієнтів фенотипної консолідації ознак відтворювальних якостей свиноматок різної племінної цінності наведено в таблиці 2.

Встановлено, що коефіцієнти фенотипної консолідації ознак відтворювальних якостей свиноматок різної племінної цінності коливаються у межах від $-0,121$ до $+0,561$.

Високий рівень фенотипної консолідації за ознаками відтворювальних якостей свиноматок виявлено у тварин II групи за молочністю $\left(\mathrm{K}_{1}=0,561, \mathrm{~K}_{2}=\right.$ $0,499)$ та масою гнізда на час відлучення у віці 28 діб $\left(\mathrm{K}_{1}=0,521, \mathrm{~K}_{2}=0,472\right)$, ровесниць I групи - за багатоплідністю $\left(\mathrm{K}_{1}=0,315, \mathrm{~K}_{2}=0,410\right)$ та кількістю поросят на час відлучення $\left(K_{1}=0,296, K_{2}=0,397\right)$

Результати розрахунку коефіцієнтів парної кореляції між ознаками відтворювальних якостей та інтегрованими показниками у свиноматок великої білої породи підконтрольних стад наведено в таблиці 3.

Встановлено, що коефіцієнти кореляції між ознаками відтворювальних якостей та інтегрованими показниками $є$ достовірними і коливаються у межах від $+0,648 \pm 0,0492$ (індекс BLUP (материнська лінія) $\times$ молочність) до $+0,984 \pm 0,0086$ (індекс відтворювальних якостей $(\mathrm{IBK}) \times$ маса гнізда на час відлучення у віці 28 діб).

Зв'язок між індексом BLUP (материнська лінія), індексом вирівняності (однорідності) гнізда свиноматки за живою масою поросят на час їхнього народження й індексом відтворювальних якостей свиноматки є також достовірним і дорівнює $+0,665 \pm 0,0474$ - +0,685 \pm 0,0452 відповідно, індексом відтворювальних якостей свиноматки й індексом вирівняності (однорідності) гнізда свиноматки за живою масою поросят на час їхнього народження $-+0,842 \pm 0,0248$.

Результати розрахунку економічної ефективності використання свиноматок різної племінної цінності, оцінених за методом BLUP (материнська лінія), наведено в таблиці 4. 


\section{Таблиця 1}

Показники ознак відтворювальних якостей свиноматок великої білої породи різної племінної цінності, оцінених за індексом BLUP (материнська лінія)

\begin{tabular}{|c|c|c|c|}
\hline \multirow{5}{*}{ Показники, одиниці виміру } & \multirow{5}{*}{$\begin{array}{c}\text { Біометричні } \\
\text { показники }\end{array}$} & \multicolumn{2}{|c|}{ Індекс “BLUP” (материнська лінія) } \\
\hline & & \multicolumn{2}{|c|}{ градації індексу } \\
\hline & & $109,78-128,75$ & $53,61-89,91$ \\
\hline & & \multicolumn{2}{|c|}{ група } \\
\hline & & I & II \\
\hline \multirow{4}{*}{ Багатоплідність, гол. } & $\mathrm{n}$ & 30 & 35 \\
\hline & $\bar{X} \pm S_{\bar{X}}$ & $12,9 \pm 0,21$ & $9,4 \pm 0,26$ \\
\hline & $\sigma \pm S_{G}$ & $1,20 \pm 0,155$ & $1,57 \pm 0,187$ \\
\hline & $C v \pm S_{C v}, \%$ & $9,29 \pm 1,281$ & $16,76 \pm 2,004$ \\
\hline \multirow{3}{*}{ Великоплідність, кг } & $\overline{\bar{X}} \pm S_{\bar{X}}$ & $1,38 \pm 0,021$ & $1,46 \pm 0,013$ \\
\hline & $\sigma \pm S_{G}$ & $0,11 \pm 0,014$ & $0,07 \pm 0,008$ \\
\hline & $C v \pm S_{C v}, \%$ & $7,97 \pm 1,029$ & $4,79 \pm 0,572$ \\
\hline \multirow{3}{*}{$\begin{array}{l}\text { Індекс вирівняності (однорідності) гнізда } \\
\text { свиноматки за живою масою поросят на час } \\
\left.\text { ix народження (IBГ }{ }_{0}\right) \text {, бала }\end{array}$} & $\bar{X} \pm S_{\bar{X}}$ & $6,11 \pm 0,112$ & $4,39 \pm 0,135$ \\
\hline & $\sigma \pm S_{G}$ & $0,61 \pm 0,078$ & $0,80 \pm 0,095$ \\
\hline & $C v \pm S_{C v}, \%$ & $10,10 \pm 1,304$ & $18,27 \pm 2,185$ \\
\hline \multirow{3}{*}{ Молочність, кг } & $\bar{X} \pm S_{\bar{X}}$ & $62,8 \pm 1,46$ & $45,3 \pm 0,69$ \\
\hline & $\sigma \pm S_{G}$ & $8,03 \pm 1,037$ & $4,09 \pm 0,489$ \\
\hline & $C v \pm S_{C v}, \%$ & $12,78 \pm 1,651$ & $9,04 \pm 1,081$ \\
\hline \multirow{3}{*}{ Кількість поросят на час відлучення, гол. } & $\bar{X} \pm S_{\bar{X}}$ & $11,0 \pm 0,19$ & $8,0 \pm 0,17$ \\
\hline & $\sigma \pm S_{G}$ & $1,00 \pm 0,129$ & $1,05 \pm 0,125$ \\
\hline & $C v \pm S_{C v}, \%$ & $9,84 \pm 1,271$ & $13,10 \pm 1,566$ \\
\hline \multirow{3}{*}{$\begin{array}{l}\text { Маса гнізда на час відлучення, у віці } 28 \text { діб, } \\
\text { кг }\end{array}$} & $\bar{X} \pm S_{\bar{X}}$ & $85,6 \pm 1,54$ & $67,3 \pm 0,79$ \\
\hline & $\sigma \pm S_{G}$ & $8,46 \pm 1,093$ & $4,68 \pm 0,559$ \\
\hline & $C v \pm S_{C v}, \%$ & $9,88 \pm 1,276$ & $6,96 \pm 0,832$ \\
\hline Збереженість поросят до відлучення, \%. & $\bar{X}$ & 85,27 & 85,10 \\
\hline \multirow{4}{*}{ IBK, бала } & $\lim$ & $101,43-161,72$ & $84,46-113,86$ \\
\hline & $\bar{X} \pm S_{\bar{X}}$ & $126,7 \pm 2,27$ & $95,63 \pm 1,48$ \\
\hline & $\sigma \pm S_{G}$ & $12,44 \pm 1,607$ & $8,78 \pm 1,050$ \\
\hline & $C v \pm S_{C v}, \%$ & $9,82 \pm 1,268$ & $9,19 \pm 1,099$ \\
\hline
\end{tabular}

Таблиця 2

Коефіцієнт фенотипної консолідації відтворювальних якостей свиноматок різної племінної цінності

\begin{tabular}{|c|c|c|c|}
\hline \multirow[b]{2}{*}{ Показники, одиниці виміру } & \multirow{2}{*}{$\begin{array}{c}\text { Коефіцієнт } \\
\text { фенотипної } \\
\text { консолідації }\end{array}$} & \multicolumn{2}{|c|}{ Група } \\
\hline & & I & II \\
\hline \multirow{2}{*}{ Багатоплідність, гол. } & $\mathrm{K}_{1}$ & 0,315 & 0,071 \\
\hline & $\mathrm{K}_{2}$ & 0,410 & $-0,091$ \\
\hline \multirow{2}{*}{ Великоплідність, кг } & $\mathrm{K}_{1}$ & $-0,037$ & 0,290 \\
\hline & $\mathrm{K}_{2}$ & $-0,052$ & 0,313 \\
\hline \multirow{2}{*}{ Молочність, кг } & $\mathrm{K}_{1}$ & 0,162 & 0,561 \\
\hline & $\mathrm{K}_{2}$ & 0,309 & 0,499 \\
\hline \multirow{2}{*}{ Кількість поросят на час відлучення, гол. } & $\mathrm{K}_{1}$ & 0,296 & 0,303 \\
\hline & $\mathrm{K}_{2}$ & 0,397 & 0,187 \\
\hline \multirow{2}{*}{ Маса гнізда на час відлучення у віці 28 діб, кг } & $\mathrm{K}_{1}$ & 0,155 & 0,521 \\
\hline & $\mathrm{K}_{2}$ & 0,266 & 0,472 \\
\hline \multirow{2}{*}{ Збереженість поросят до відлучення, \%. } & $\mathrm{K}_{1}$ & 0,118 & $-0,121$ \\
\hline & $\mathrm{K}_{2}$ & 0,122 & $-0,105$ \\
\hline
\end{tabular}


Таблиця 3

Коефіцієнт парної кореляції між ознаками власної продуктивності, відтворювальних якостей та інтегрованими показниками зазначених груп ознак у свиней великої білої породи, $\mathrm{n}=65$

\begin{tabular}{llcc}
\hline \multicolumn{1}{c}{ Ознака } & \multicolumn{2}{c}{ Біометричні показники } \\
\hline \multicolumn{1}{c}{$x$} & $y$ & $r \pm S r$ & $t r$ \\
\hline \multirow{2}{*}{ Індекс BLUP (материнська лінія), бала } & 1 & $0,710 \pm 0,0422^{* * *}$ & 16,81 \\
& 2 & $0,648 \pm 0,0492^{* * *}$ & 13,12 \\
& 3 & $0,667 \pm 0,0471^{* * *}$ & 14,11 \\
Індекс “вирівняність (однорідність) гнізда свино- & 4 & $0,657 \pm 0,0471^{* * *}$ & 107,80 \\
матки за живою масою поросят на час народжен- & 2 & $0,947 \pm 0,0088^{* * *}$ & 20,23 \\
ня”, бала & 3 & $0,751 \pm 0,0371^{* * *}$ & 42,75 \\
& 4 & $0,872 \pm 0,0204^{* * *}$ & 21,56 \\
\multirow{2}{*}{ Індекс відтворювальних якостей (ІВК), бала } & 1 & $0,764 \pm 0,0354^{* * *}$ & 55,06 \\
& 2 & $0,899 \pm 0,0163^{* * *}$ & 264,00 \\
& 3 & $0,978 \pm 0,0037^{* * *}$ & 231,36 \\
\hline
\end{tabular}

Примітка: 1 - багатоплідність, гол.; 2 - молочність, кг; 3 - кількість поросят на час відлучення, гол.; 4 - маса гнізда на час відлучення, у віці 28 діб, кг, *** - $\mathrm{P}<0,001$

\section{Таблиця 4}

Економічна ефективність використання свиноматок різної племінної цінності, оцінених за методом BLUP (материнська лінія)

\begin{tabular}{ccccc}
\hline $\begin{array}{c}\text { Клас розподілу за індексом BLUP } \\
\text { (материнська лінія)/ група }\end{array}$ & $\mathrm{n}$ & $\begin{array}{c}\text { Маса гнізда на час від- } \\
\text { лучення у віці } 28 \text { діб, кг }\end{array}$ & $\begin{array}{c}\text { Прибавка додаткової } \\
\text { продукції, \% }\end{array}$ & $\begin{array}{c}\text { Вартість додаткової } \\
\text { продукції, грн/гол.* }\end{array}$ \\
\hline Загальна вибірка & 65 & $74,4 \pm 0,82$ & - & - \\
II & 35 & $67,3 \pm 0,79$ & $-9,54$ & $-242,21$ \\
I & 30 & $85,6 \pm 1,54$ & $+13,08$ & $+332,08$ \\
\hline
\end{tabular}

Примітка: * - середня ціна реалізації молодняку свиней на переробні підприємства регіону дорівнювала 45,5 грн/кг

Встановлено, що максимальну прибавку додаткової продукції одержано від свиноматок I групи, у яких індекс BLUP (материнська лінія) дорівнює 109,78-128,75, індекс відтворювальних якостей (IBК) - 101,43-161,72 бала $-+13,08 \%$, а іiі вартість становить $+332,08$ грн/гол.

\section{Висновки}

1. За результатами досліджень встановлено, що максимальними показниками багатоплідності (12,9 гол.), молочності (62,8 кг), кількості поросят (11,0 гол.) та маси гнізда на час відлучення у віці 28 діб (85,6 кг) характеризуються свиноматки II групи, у яких індекс BLUP (материнська лінія) дорівнює 109,78-128,75, індекс відтворювальних якостей (ИВК) - 101,43-161,72 бала.

2. Високий рівень фенотипної консолідації за ознаками відтворювальних якостей свиноматок виявлено у тварин II групи за молочністю $\left(\mathrm{K}_{1}=0,561\right.$, $\left.\mathrm{K}_{2}=0,499\right)$ та масою гнізда на час відлучення у віці 28 діб $\left(\mathrm{K}_{1}=0,521, \mathrm{~K}_{2}=0,472\right)$, ровесниць I групи - за багатоплідністю $\left(\mathrm{K}_{1}=0,315, \mathrm{~K}_{2}=0,410\right)$ та кількістю поросят на час відлучення $\left(K_{1}=0,296, K_{2}=0,397\right)$.

3. Коефіцієнти кореляції між ознаками відтворювальних якостей та інтегрованими показниками є достовірними і коливаються у межах від $+0,648 \pm 0,0492$ (індекс BLUP (материнська лінія) $\times$ молочність) до $+0,984 \pm 0,0086$ (індекс відтворювальних якостей (ИВК) $\times$ маса гнізда на час відлучення у віці 28 діб).
4. Розрахунок економічної ефективності використання свиноматок різної племінної цінності свідчить, що максимальну прибавку додаткової продукції одержано від свиноматок I групи, у яких індекс BLUP (материнська лінія) дорівнює 109,78-128,75, індекс відтворювальних якостей (IBK) - 101,43-

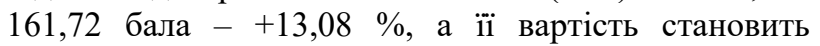
$+332,08$ грн/гол. Зазначені показники оціночних індексів є критерієм відбору висопродуктивних свиноматок великої білої породи підконтрольних стад.

\section{References}

Balatsky, V. N., Saenko, A. M. \& Grishina, L. P. (2012). Polymorphism of the estrogen receptor 1 locus in populations of pigs of different genotypes and its association with reproductive traits of large white sows. Cytol. Genet., 46, 233-237. doi: 10.3103/S0095452712040020.

Bazhov, G. M., \& Komlatskiy, V. I. (1989). Biotekhnologiya intensivnogo svinovodstva. [Biotechnology of intensive pig breeding]. Moskva: Rosagropromizdat (in Russian).

Berezovs'kyy, M. D., \& Khat'ko, I. V. (2005). Metodyky otsinky knuriv i svynomatok za yakistyu potomstva $\mathrm{v}$ umovakh pleminnykh zavodiv i pleminnykh reproduktoriv. [Methods for assessing boars and sows on the quality of offspring in breeding plants and breeding breeders] Suchasni metodyky doslidzhen' u svynarstvi. Poltava, 32-37 (in Ukrainian). 
Chinarov, Yu., Zinov'yeva, N., \& Yernst, L. (2007). Metod plemennoy otsenki sviney na osnove BLUP. [Method of breeding assessment of pigs based on BLUP]. Zhivotnovodstvo Rossii, 2, 45-46 (in Russian).

Danshin, V. A. (2008). Otsenka geneticheskoy tsennosti zhivotnykh [Assessment of the genetic value of animals]. K.: Agrarna nauka (in Russian).

Ibánẽz-Escriche, N., Fernando, R. L., Toosi, A. et al. (2009). Genomic selection of purebreds for crossbred performance. Genet Sel Evol, 41, 12. doi: 10.1186/1297-9686-41-12.

Khalak, V. I. (2012). Sposib vyznachennya vyrivnyanosti hnizda svynomatok (2012) [The method of determining the alignment of the sow's nest] patent 66551 Ukrayina, MPK (2011.01) A 01K 67/02 (2006.01), A 61D 19/00.; zayavnyk patentu Instytut tvarynnytstva tsentral'nykh rayoniv UAAN, vlasnyk patentu DU Instytut sil's'koho hospodarstva stepovoyi zony NAAN. № u 2011007148; zayavl. 06.06.2011; opubl. 10.01.2012, Byul. № 1. URL: https://uapatents.com/266551-sposib-viznachennya-virivnyanosti-gnizdasvinomatok.html (in Ukrainian).

Khalak, V. I. (2015). Nekotoryye selektsionnyye priznaki sviney i ikh otsenka $\mathrm{s}$ ispol'zovaniyem innovatsionnykh metodov [Some breeding traits of pigs and their assessment using innovative methods]. Nauchnyy faktor v strategii innovatsionnogo razvitiya svinovodstva: sb. materialov XXII mezhdunarodnoy nauchno-prakticheskoy konferentsii; Grodno: GAU, 140-145 (in Russian).

Khalak, V. I. (2020). Hen retseptoru melanokortyna 4 (Mc4r) - efektyvnyy marker vidhodivel'nykh i m'yasnykh yakostey molodnyaku svyney velykoyi biloyi porody zarubizhnoho pokhodzhennya. [Melanocortin 4 receptor gene (Mc4r) is an effective marker of fattening and meat qualities of young pigs of large white breed of foreign origin]. Aktual'ni problemy pidvyshchennya yakosti ta bezpeka vyrobnytstva y pererobky produktsiyi tvarynnytstva: materialy Mizhnar. nauk.-prakt. konf. (m. Dnipro, 14 lyutoho 2020 r.). Dnipro, 148-151. URL: http://dspace.dsau.dp.ua/jspui/handle/123456789/2097 (in Ukrainian).

Khalak, V., Gutyj, B., Bordun, O., Ilchenko, M., \& Horchanok, A. (2020). Effect of blood serum enzymes on meat qualities of piglet productivity. Ukrainian Journal of Ecology, 10(1), 158-161. doi: 10.15421/2020_25.

Khalak, V., Gutyj, B., Bordun, O., Horchanok, A., Ilchenko, M., Smyslov, S., Kuzmenko, O., \& Lytvyshchenko, L. (2020). Development and reproductive qualities of sows of different breeds: innovative and traditional methods of assessment. Ukrainian Journal of Ecology, 10(2), 356-360 doi: 10.15421/2020_109.

Khalak, V., Gutyj, B., Bordun, O., Horchanok, A., Ilchenko, M., Smyslov, S., Lytvyshchenko, L., \& Kuzmenko, L. (2020). Large White breed sows. Ukrainian Journal of Ecology, 10(4), 122-126. doi: $10.15421 / 2020178$.
Kozyr, V., Khalak, V., \& Povod, M. (2019). DNA-type results swine for MS4R-gene and its association with productivity. Agrolife: Scientific journal. University of Agronomic Sciences and Veterinari Medicine of Bucharest. Bucharest, 8(1), 128-133. URL: http://agrolifejournal.usamv.ro/pdf/vol.VIII_1/Art16.pdf.

Lakin, G. F. (1990). Biometriya [Biometrics]. Moskva (in Russian).

Metodika opredeleniya ekonomicheskoy effektivnosti ispol'zovaniya $\mathrm{v}$ sel'skom khozyaystve rezul'tatov nauchno-issledovatel'skikh rabot, novoy tekhnologii, izobreteniy i ratsionalizatorskikh predlozheniy (1983). [Methodology for determining the economic efficiency of the use in agriculture of the results of scientific research, new technology, inventions and rationalization proposals] Moskva: VAIIPI (in Russian).

Polupan, Yu. P. (1996) Otsenka stepeni fenotipicheskoy konsolidatsii genealogicheskikh grupp zhivotnykh. [Assessment of the degree of phenotypic consolidation of genealogical groups of animals]. Zootekhniya, 10, 13-15 (in Russian).

Rybalko, V. P., \& Floka, L. V. (2014). Vplyv fenotypovykh faktoriv na produktyvni yakosti svyney chervono-bilopoyasoyi porody [Influence of phenotypic factors on productive qualities of pigs of redwhite-belt breed] Monohrafiya. Poltava: RVV PUET (in Ukrainian).

Schiavo, G., Galimberti, G., Calo, D. G. et al. (2015). Twenty years of artificial directional selection have shaped the genome of the Italian Large White pig breed. Animal Genetics, 47(2), 181-191. doi: 10.1111/age.12392.

Sheyko, I. P., Loban, N. A., Vasilyuk, O. Ya., Petrushko, I. S., Chernov, A. S., \& Sheyko, R. I. (2008). Sposob kompleksnoy otsenki reproduktivnykh kachestv svinomatok [A method for a comprehensive assessment of the reproductive qualities of sows] patent RF № $2340178 \mathrm{~S}$ 2, A $01 \mathrm{~K} \quad 67 / 02$; ; zayavitel' i patentoobladatel' Nauchno-prakticheskiy tsentr Natsional'noy akademii nauk Belarusi po zhivotnovodstvu. № 2006118083; zayavl. 26.05.2006; opubl. 10.12.2008, Byul. № 34 (in Russian).

Tserenyuk, O. M., Khvatov, F. I., \& Stryzhak T. A. (2010). Efektyvnist' selektsiynykh i otsinochnykh indeksiv materyns'koyi produktyvnosti svyney [Efficiency of selection and evaluation indices of maternal productivity of pigs]. Nauk. tekhn. byul. Instytutu NAAN. Kharkiv, 102, 173-183 (in Ukrainian).

Voloshchuk, V. M., \& Khalak, V. I. (2015). Produktyvnist' svyney riznoyi pleminnoyi tsinnosti ta klasiv rozpodilu za indeksamy O. Vanhena ta A. Sazera, KH. Fredina. [Productivity of pigs of different breeding value and distribution classes according to the indices of O. Wangen and A. Sazer, H. Fredin]. Svynarstvo. Mizhvidomchyy tematychnyy nauk. zb. Instytutu svynarstva i APV NAAN. Poltava, 67, 8186 (in Ukrainian). 